\title{
Morbidity Pattern among Out-Patients Attending Urban Health Training Centre in Srinagar
}

\author{
Santosh Kumar', Haroon AS ${ }^{2}$, Amit Kumar ${ }^{2}$, Abhisek Raj ${ }^{4}$ \\ 1,4 Department of Community Medicine, AIIMS, Rishekesh, Uttarakhand, India \\ ${ }^{2}$ Department of Community Medicine, VCSG Govt. Medical Sc. \& RI, Srinagar, Uttarakhand, India
}

\begin{tabular}{l} 
Article Info \\
\hline Article history: \\
Received Jan 4, 2018 \\
Revised Mar 7, 2018 \\
Accepted Mar 26, 2018 \\
\hline
\end{tabular}

Keyword:

Communicable diseases

Morbidity pattern

Non communicable diseases

\begin{abstract}
The current study was designed to identify the morbidity pattern of outpatients attending Urban Health Training Centre in an urban area of a medical college in Srinagar, Pauri Garhwal district, Uttarakhand, North India. The present study record-based retrospective study was conducted among the out-patients attending the regular clinic at the Urban Health Training Centre, of a medical college in Srinagar city of Uttarakhand State of North India during the study period of one year in 2014. Data was retrieved from the OPD registers maintained at the clinic. Data was collected pertaining to socio-demographic profile, morbidity details and treatment pattern. Diseases were identified using the International Classification of Diseases (ICD-10) code. Descriptive analysis was done. During the study period, a total of 9343 subjects attended the OPD. Among them, majority of them $(60 \%)$ were females. More than half $(56 \%)$ belonged to the age group of 35-65 year age-group. The association of disease classification was found to be statistically significant with respect to gender. The leading morbidity of communicable disease was found to be certain infectious and parasitic diseases especially Typhoid whereas musculoskeletal system and connective tissue disorders were the most common cause among morbidity due to NCDs. Out of all, typhoid was found to cause maximum of morbidity among the subjects. The present study highlights the morbidity pattern of communicable and NCDs among the population of hilly areas of Garhwal, Uttarakhand India. Priority should be preferred for the regular tracking of diseases in terms of preventive and promotive aspects. Morbidity in the outdoor clinics reflects the emerging trend of mixed disease spectrum burden comprising communicable and non-communicable diseases.
\end{abstract}

Copyright (c) 2018 Institute of Advanced Engineering and Science. All rights reserved.

\section{Corresponding Author:}

Haroon Ali,

Department of Community Medicine,

Veer Chandra Singh Garhwali Govt. Medical Science \& Research Institute,

Uttarakhand, India, Tel: 01364-244701, Fax: 01364-244702.

E-mail: haroonali1978@gmail.com

\section{INTRODUCTION}

India is a large country witnessing huge variations in the health indicators across states and districts of the country. Though there exists few Indian studies that have been documenting the morbidity profile of their population, even today there exists a wide paucity of adequate information related to morbidity and mortality data at the facility level especially Uttarakhand [1].

The health of an individual does have a direct relationship with human resources development and economic development of a nation. From the time of Alma Ata declaration to achieve "Health for All by 2000", lot of planning, effort and public expenditure had been devoted to improve the health of the people both in rural and urban areas of India. Further, the spread and accessibility of medical care has also improved 
substantially across the country. However, despite of these efforts, India is one of the many developing countries, which have high levels of morbidity [2].

However, India has made significant progress in improving the health conditions of its population. While there has been a general decrease in mortality leading to significant gains in life expectancy, what has happened to morbidity is yet to be assessed. Very little information is available about the disease people of different population groups in India. The level and prevalent pattern of morbidity in the country show that India has entered into the fourth stage of health transition [3]. Due to industrialization and the persisting inequality in health status between and within States and Union Territories (due to varying economic, social and political reasons), India currently faces a "Triple burden of diseases", which include unfinished agenda of communicable diseases, emerging non-communicable diseases related to lifestyles and emerging infectious diseases [4].

Geographically, Uttarakhand state is having a higher prevalence rate of some major communicable diseases especially tuberculosis (170/ lakh population), malaria (14\% of all fever cases) and a greater vulnerability towards HIV/AIDS. Due to negative lifestyle practice, there are increasing trends in the prevalence of non-communicable diseases (NCDs) as well [5]. The prevalence of high-risk factors for these chronic diseases like hypertension, dyslipidaemia, and diabetes mellitus is quite high among the elderly population, especially amongst urban counterparts [6].

Health is an important determinant of wellbeing. It is positively related to labour productivity and economic efficiency. Therefore, maintaining good health is important for an individual or a household at the micro level and for the society at the macro level. Health status in most developing countries is constrained by poor working and living conditions on the one hand and supply and demand factors on the other.

The concept of health, disease and treatment are related to the social structure of the community. Our health is affected not by only unbalanced diet but also by the disease, which may be water borne, airborne, or food borne. More than how what a person looks like and how intelligent he or she might be, genes are the most determining factors to decide whether a person will be predisposed to certain illness like specific cancer, heart problems, diabetes and obesity.Loss of life and morbidity are the important components of human welfare. Connections between mortality and morbidity are an area of wider discussions in the present Indian context. The current health scenario in India is often described as "Dismal" or "Disturbing". In a difficult terrain of a Hilly state of India the morbidity statistics was completely untouched. This study was able to explore the patterns of disease and the high risk population among this community .Even though the life expectancy of Indians has increased in the last few decades, the level of morbidity is still in a pathetic condition.

\section{MATERIAL AND METHODS}

\subsection{Study design and Study setting}

The present record-based cross-sectional study was carried out at an Urban Health Training Centre (UHTC) under the Department of Community Medicine, of a medical college located on the banks of Alaknanda river in the northern part of Uttarakhand, India. The UHTC covers the entire population of district, Pauri Garhwal, located at the foothills of Himalayan ranges at an average altitude of 1650 meters. The district covers the population of around 684,743 and is spread over a geographical area of $5230 \mathrm{kms}^{2}$ at a

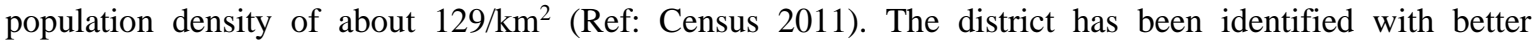
indicators including a commendable literacy rate of $82 \%$. Modern medicine facilities are easily accessible to the people in the area, both Government and private. In addition, the Department of Community Medicine provides primary health care to the population, through Rural and Urban Health Training Centres, which is provided at no cost to the patients. These primary centres are well connected to the tertiary care Hemwati Nandan Bahuguna, Base teaching hospital at Srinagar city of Uttarakhand. Equipped with the state-of-the-art infrastructure, the hospitals have the full-fledged working Obstetrics \& Gynecology, Pediatrics, General Medicine, Ophthalmology and other departments.

\subsection{Study variables and instrument}

Institutional ethical clearance was obtained prior to the conduct of the study. Data was retrieved from the out-patient registers maintained at the centre and was collected retrospectively for the period of one year from $1^{\text {st }}$ January to $31^{\text {st }}$ December, 2014. Main domains of the data collected were: socio-demographic details of the study subjects and their medical details pertaining to disease profile - diagnosis, treatment, and further management. Each patient was identified with a unique registration number from the health records. Only newly diagnosed patients were included in the study. Data of all those patients who came for repeated follow-up check-ups from the previous years were excluded from the study. Diseases were uniformly defined 
as per World Health Organization (WHO) standards of International Classification of Diseases (ICD) code 10 , classified into communicable and non communicable diseases.

\subsection{Statistical analysis}

Data were entered in Microsoft Excel and were analyzed using software Statistical Package for Social Sciences (SPSS) version 21.0 and R software version 3.3. Results were expressed as proportions or mean \pm standard deviation for categorical and continous variables respectively. Discrete data were analyzed using Pearson's Chi-square test to see the significance of observed differences between males and females. $P$ values $<0.05$ were considered significant.

\section{RESULTS}

In the present study, a total of 9343 subjects attended the OPD. The age-wise and gender-wise distribution of the study population has been shown in Table 1. Of the total, 3759 (40.2\%) were males and $5584(59.8 \%)$ were females (sex ratio: 1485 per 1000 males. More than half of the subjects (54.6\%) belonged to the age group of 35-64 years of age group [males: 1970 (52.2\%), females: $3133(56.1 \%)$ ]. The study showed an overall difference in the proportion of morbidities to be statistically significant with respect to gender $(\mathrm{p}<.0001)$.

Table 1. Age-wise and Gender-wise distribution of the study subjects $(\mathrm{N}=9343)$

\begin{tabular}{cccccccc}
\hline \multirow{2}{*}{ Age Group } & Male & $\%$ & Female & $\%$ & Total & $\%$ & Z Statistics with \\
& 286 & 7.6 & 275 & 4.9 & 561 & 6.0 & $0.5(\mathrm{p}>.05)$ \\
\hline $0-14$ & 967 & 25.7 & 1598 & 28.6 & 2565 & 27.5 & $11.8(\mathrm{p}<.0001)$ \\
$15-34$ & 1970 & 52.4 & 3133 & 56.1 & 5103 & 54.6 & $15.3(\mathrm{p}<.0001)$ \\
$35-64$ & 536 & 14.3 & 578 & 10.4 & 1114 & 11.9 & $1.3(\mathrm{p}>.05)$ \\
$65+$ & 3759 & 40.2 & 5584 & 59.8 & 9343 & 100 & $19.0(\mathrm{p}<.0001)$ \\
Total & & & & & & \\
\hline
\end{tabular}

Among the total study subjects, less than three-fourths of the subjects $(n=6510 ; 70 \%)$ were suffering from non-communicable diseases whereas remaining were diagnosed with communicable diseases $(n=2837$; 30\%). Table 2 and Table 3 depicted the gender-wise distribution of morbidity pattern with respect to both communicable and non-communicable diseases respectively. Among the subjects suffering from communicable diseases, more than half of them were females $(n=1681 ; 59 \%)(p<0.001)$. The most common cause was found to be certain infectious and parasitic diseases manly typhoid. The association between gender and classification of diseases was found to be statistically significant for ICD-10:A00-B99; J00-J99, N00-N99, except J12 disease (Figure 1).

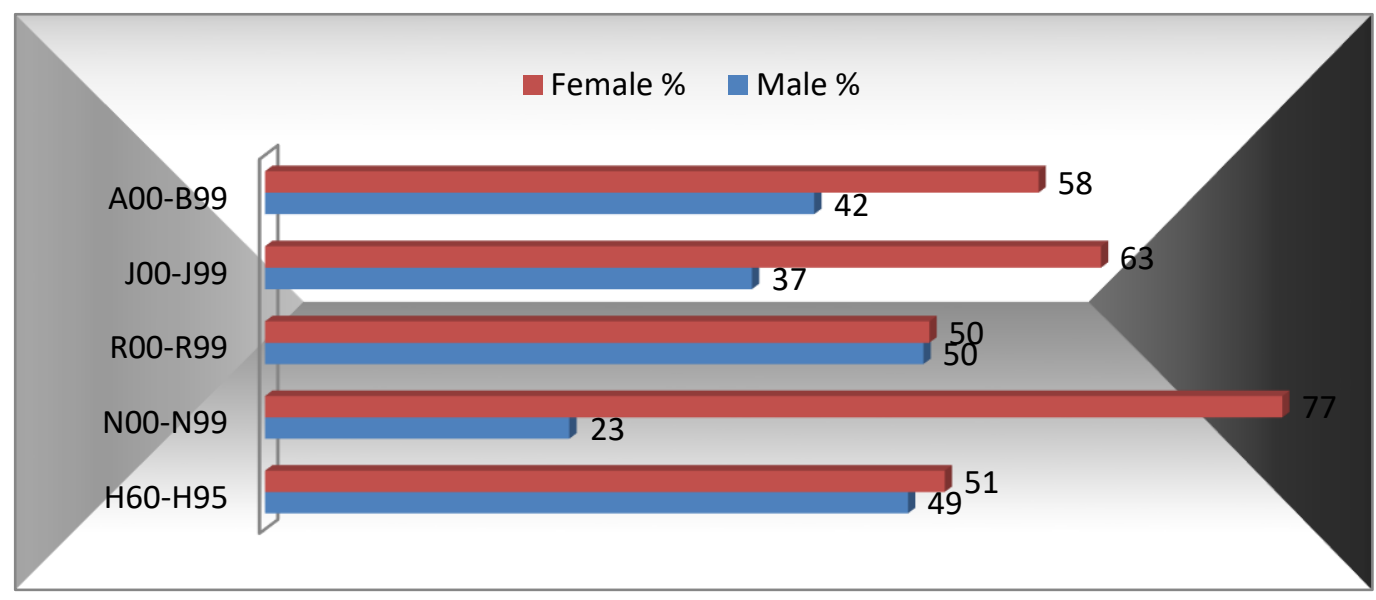

Figure 1. The Distribution pattern of morbidity due to communicable diseases morbidity with regard to gender 
Table 2. Distribution of Morbidity Patterns of Communicable Diseases with respect to gender (N=2837)

\begin{tabular}{|c|c|c|c|c|c|c|c|c|}
\hline \multirow{2}{*}{ ICD 10} & \multirow{2}{*}{ Name of main and sub Diseases } & \multicolumn{2}{|c|}{ Male Morbidity } & \multicolumn{2}{|c|}{ Female Morbidity } & \multicolumn{2}{|c|}{ Total Morbidity } & \multirow{2}{*}{$\begin{array}{l}Z \text { Statistics with p } \\
\text { value }\end{array}$} \\
\hline & & $\#$ & $\%$ & $\#$ & $\%$ & & $\%$ & \\
\hline & $\begin{array}{l}\text { Certain infectious and parasitic } \\
\text { diseases }\end{array}$ & 524 & 42 & 738 & 58 & 1262 & 44.5 & $5.6(p<.0001)$ \\
\hline \multirow[t]{2}{*}{$\mathrm{A} 00-\mathrm{B} 99$} & $\begin{array}{ll}\text { Typhoid } & \text { A01 } \\
\text { Gastroenteritis } & \text { A02 } \\
\text { Scabies } & \text { B86 }\end{array}$ & $\begin{array}{l}256 \\
125 \\
65\end{array}$ & $\begin{array}{l}37 \\
63 \\
37\end{array}$ & $\begin{array}{c}427 \\
74 \\
111\end{array}$ & $\begin{array}{l}63 \\
37 \\
63\end{array}$ & $\begin{array}{l}683 \\
199 \\
176\end{array}$ & $\begin{array}{c}24.1 \\
7.0 \\
6.2\end{array}$ & $\begin{array}{l}6.6(p<.0001) \\
3.6(p<.001) \\
3.3(p<001)\end{array}$ \\
\hline & Diseases of the ear andmastoid & & & & & & & \\
\hline H60-H95 & $\begin{array}{ll}\text { process } & \\
\text { CSOM } & \mathrm{H} 65\end{array}$ & 35 & 49 & 37 & 51 & 72 & 2.5 & $0.2(p>05)$ \\
\hline \multirow[t]{2}{*}{ J00-J99 } & $\begin{array}{lr}\text { Diseases of the respiratory system } \\
\text { Viral fever } & \text { J10 } \\
\text { Pneumonia } & \mathrm{J} 12 \\
\text { Pharyngitis } & \mathrm{J} 02\end{array}$ & $\begin{array}{l}293 \\
120 \\
80 \\
23\end{array}$ & $\begin{array}{l}37 \\
33 \\
44 \\
25\end{array}$ & $\begin{array}{c}503 \\
242 \\
103 \\
70\end{array}$ & $\begin{array}{l}63 \\
67 \\
56 \\
75\end{array}$ & $\begin{array}{c}796 \\
362 \\
183 \\
93\end{array}$ & $\begin{array}{l}28.1 \\
12.8 \\
6.5 \\
3.3\end{array}$ & $\begin{array}{c}7.1(p<.0001) \\
6.1(p<.0001) \\
1.6(p>05) \\
4.3(p<.0001)\end{array}$ \\
\hline & Diseases of the genitourinary system & 49 & 23 & 164 & 77 & 213 & 7.5 & $6.9(p<0001)$ \\
\hline \multirow[t]{2}{*}{ No0-N99 } & UTI $\quad$ N39 & 36 & 37 & 62 & 63 & 98 & 3.5 & $2.5(p<.05)$ \\
\hline & PID $\quad$ N70 & 13 & 11 & 102 & 89 & 115 & 4.1 & $6.6(p<.0001)$ \\
\hline \multirow[t]{3}{*}{ R00-R99 } & $\begin{array}{l}\text { Symptoms, signs and abnormal } \\
\text { clinical and laboratory findings, not } \\
\text { els ewhere classified }\end{array}$ & 220 & 50 & 222 & 50 & 442 & 15.6 & $0.0(p=1)$ \\
\hline & Jaundice & & & & & & & \\
\hline & $\begin{array}{l}\text { Other } \\
\text { Total }\end{array}$ & $\begin{array}{c}31 \\
1152\end{array}$ & $\begin{array}{l}60 \\
41\end{array}$ & $\begin{array}{c}21 \\
1681\end{array}$ & $\begin{array}{l}40 \\
59\end{array}$ & $\begin{array}{c}52 \\
2837\end{array}$ & $\begin{array}{l}1.8 \\
100\end{array}$ & $\begin{array}{l}1.4(p>05) \\
9.4(p<.0001)\end{array}$ \\
\hline
\end{tabular}

Table 3. Gender-wise Distribution of Morbidity Patterns of Non-communicable Diseases among the study population $(\mathrm{N}=6510)$

\begin{tabular}{|c|c|c|c|c|c|c|c|c|c|}
\hline \multirow{2}{*}{ ICD 10} & \multirow{2}{*}{\multicolumn{2}{|c|}{ Name of Disease }} & \multicolumn{2}{|c|}{ Male Morbidity } & \multicolumn{2}{|c|}{ Female Morbidity } & \multicolumn{2}{|c|}{ Total Morbidity } & \multirow{2}{*}{$\begin{array}{l}\text { Z Statistics with } \\
\text { p value }\end{array}$} \\
\hline & & & \# & $\%$ & \# & $\%$ & \# & $\%$ & \\
\hline \multirow[t]{2}{*}{ D50-D89 } & $\begin{array}{l}\text { Diseases of the blood and blood-form } \\
\text { organs and certain }\end{array}$ & & 100 & 39 & 156 & 61 & 256 & 3.9 & $3.4(\mathrm{p}<.001)$ \\
\hline & Anaemia & D50 & 100 & 40 & 151 & 60 & 251 & 3.9 & $3.1(\mathrm{p}<.05)$ \\
\hline \multirow[t]{4}{*}{ E00-E89 } & Endocrine, nutritional and metabolic & diseases & 127 & 45 & 154 & 55 & 281 & 4.3 & $1.7(\mathrm{p}>.05)$ \\
\hline & Diabetes Mellitus & E10 & 76 & 40 & 116 & 60 & 192 & 2.9 & $2.7(\mathrm{p}<.05)$ \\
\hline & Hypertension with Diabetes & E11.22 & 17 & 55 & 14 & 45 & 31 & 0.5 & $0.6(\mathrm{p}>.05)$ \\
\hline & Vitamin A Deficiency & E50 & 12 & 52 & 11 & 48 & 23 & 0.4 & $0.2(\mathrm{p}>.05)$ \\
\hline \multirow[t]{4}{*}{ F00-F99 } & $\begin{array}{l}\text { Mental, Behavioural and Neurodevel } \\
\text { disorders }\end{array}$ & opmental & 147 & 26 & 411 & 74 & 558 & 8.6 & $10.3(\mathrm{p}<.0001)$ \\
\hline & Depression & F32.8 & 47 & 18 & 219 & 82 & 266 & 4.1 & $8.7(\mathrm{p}<.0001)$ \\
\hline & APD & F40 & 71 & 33 & 142 & 67 & 213 & 3.3 & $4.7(\mathrm{p}<.0001)$ \\
\hline & OCD & $\mathrm{F} 42$ & 12 & 33 & 24 & 67 & 36 & 0.6 & $1.9(\mathrm{p}>.051)$ \\
\hline \multirow[t]{4}{*}{ G00-G99 } & Diseases of the nervous system & & 202 & 27 & 547 & 73 & 749 & 11.5 & $11.4(\mathrm{p}<.0001)$ \\
\hline & Migraine & G43 & 47 & 19 & 196 & 81 & 243 & 3.7 & $8.3(\mathrm{p}<.0001)$ \\
\hline & Tension Headache & G44.2 & 101 & 29 & 250 & 71 & 351 & 5.4 & $7.2(\mathrm{p}<.0001)$ \\
\hline & Neuropathy & G64 & 45 & 34 & 89 & 66 & 134 & 2.1 & $3.5(\mathrm{p}<.001)$ \\
\hline \multirow[t]{2}{*}{ H60-H95 } & Diseases of the ear and mastoid proce & & 34 & 30 & 78 & 70 & 112 & 1.7 & $4.7(\mathrm{p}<.0001)$ \\
\hline & Vertigo & H81 & & & & & & & \\
\hline \multirow[t]{4}{*}{ I00-I99 } & Diseases of the circulatory system & & 431 & 45 & 524 & 55 & 955 & 14.7 & $3.1(\mathrm{p}<.05)$ \\
\hline & Hypertension & $\mathrm{I} 10$ & 279 & 49 & 288 & 51 & 567 & 8.7 & $0.5(\mathrm{p}>.05)$ \\
\hline & Ischemic Heart Disease & $\mathrm{I} 25$ & 75 & 34 & 143 & 66 & 218 & 3.3 & $4.5(\mathrm{p}<.0001)$ \\
\hline & $\mathrm{CHF}$ & I50 & 28 & 57 & 21 & 43 & 49 & 0.8 & $1.0(\mathrm{p}>.05)$ \\
\hline \multirow[t]{3}{*}{ J00-J99 } & Diseases of the respiratory system & & 322 & 63 & 191 & 37 & 513 & 7.9 & $5.7(\mathrm{p}<.0001)$ \\
\hline & COPD & $\mathrm{J} 40$ & 272 & 60 & 183 & 40 & 455 & 7.0 & $4.2(\mathrm{p}<.0001)$ \\
\hline & Asthma & $\mathrm{J} 45$ & 47 & 92 & 4 & 8 & 51 & 0.8 & $4.6(\mathrm{p}<.0001)$ \\
\hline \multirow[t]{4}{*}{ K00-K95 } & Diseases of the digestive system & & 478 & 47 & 536 & 53 & 1014 & 15.6 & $1.9(\mathrm{p}>.05)$ \\
\hline & APD & K27 & 335 & 50 & 336 & 50 & 671 & 10.3 & $0.0(\mathrm{p}=1)$ \\
\hline & IBD & K50 & 30 & 41 & 44 & 59 & 74 & 1.1 & $1.5(\mathrm{p}>.05)$ \\
\hline & IBS & K58 & 43 & 43 & 57 & 57 & 100 & 1.5 & $1.4(\mathrm{p}>.05)$ \\
\hline \multirow[t]{4}{*}{ L00-L99 } & Diseases of the skin and subcutaneou & s tissue & 86 & 37 & 147 & 63 & 233 & 3.6 & $4.5(\mathrm{p}<.0001)$ \\
\hline & Allergic Dermatitis & $\mathrm{L} 23$ & 12 & 38 & 20 & 62 & 32 & 0.5 & $1.3(\mathrm{p}>.05)$ \\
\hline & Photo dermatitis & L57.8 & 27 & 63 & 16 & 37 & 43 & 0.7 & $1.7(\mathrm{p}>.05)$ \\
\hline & $\mathrm{ACNE}$ & $\mathrm{L} 70$ & 6 & 18 & 27 & 82 & 33 & 0.5 & $3.1(\mathrm{p}<.05)$ \\
\hline \multirow[t]{4}{*}{$\begin{array}{l}\text { M00- } \\
\text { M99 }\end{array}$} & $\begin{array}{l}\text { Diseases of the musculoskeletal syste } \\
\text { connective tissue }\end{array}$ & $\mathrm{m}$ and & 522 & 34 & 1002 & 66 & 1524 & 23.4 & $11.9(\mathrm{p}<.0001)$ \\
\hline & Osteoarthritis & M15 & 158 & 25 & 472 & 75 & 630 & 9.7 & $11.2(\mathrm{p}<.0001)$ \\
\hline & Lumbar Spondylolysis & M43 & 33 & 29 & 80 & 71 & 113 & 1.7 & $4.1(\mathrm{p}<.0001)$ \\
\hline & Tendinitis & M79.7 & 126 & 64 & 71 & 36 & 197 & 3.0 & $3.8(\mathrm{p}<.001)$ \\
\hline \multirow[t]{3}{*}{ N00-N99 } & Diseases of the genitourinary system & & 81 & 72 & 32 & 28 & 113 & 1.7 & $4.3(\mathrm{p}<.0001)$ \\
\hline & Renal Stone & N20 & 3 & 27 & 8 & 73 & 11 & 0.2 & $1.4(\mathrm{p}>.05)$ \\
\hline & PMS & N94.3 & 30 & 42 & 42 & 58 & 72 & 1.1 & $1.3(\mathrm{p}>.05)$ \\
\hline \multirow[t]{4}{*}{ R00-R99 } & $\begin{array}{l}\text { Symptoms, signs and abnormal clinic } \\
\text { laboratory findings, not elsewhere cla }\end{array}$ & $\begin{array}{l}\text { al and } \\
\text { ssified }\end{array}$ & 49 & 38 & 81 & 62 & 130 & 2.0 & $2.7(\mathrm{p}<.05)$ \\
\hline & LBA & $\mathrm{R} 10$ & 22 & 27 & 60 & 73 & 82 & 1.3 & $3.8(\mathrm{p}<.001)$ \\
\hline & Ascites & R18 & 14 & 64 & 8 & 36 & 22 & 0.3 & $1.3(\mathrm{p}>.05)$ \\
\hline & Muscular Cramp & $\mathrm{R} 25.2$ & 4 & 44 & 5 & 56 & 9 & 0.1 & $0.4(\mathrm{p}>.05)$ \\
\hline Other & & & 28 & 33 & 57 & 67 & 85 & 1.3 & $3.0(\mathrm{p}<.05)$ \\
\hline Total & & & 2607 & 40 & 3916 & 60 & 6510 & 100 & $15.8(\mathrm{p}<.0001)$ \\
\hline
\end{tabular}

IJPHS Vol. 7, No. 1, March 2018: $01-07$ 
Among the subjects suffering from non-communicable diseases, less than one-third of the patients were females $(n=3916 ; 60 \%) \quad(p<0.001)$. The overall association between the distribution of noncommunicable diseases with respect to gender was found to be statistically significant $(\mathrm{p}<.0001)$. The leading cause of non-communicable diseases was found to be musculoskeletal system and connective tissue. The association between gender and classification of diseases was found to be statistically significant for ICD10:M00-M99, diseases of the circulatory system [ICD-10: I00-I99], diseases of the nervous system [ICD10:G00-G99], and mental, behavioural and neuro-developmental disorders [ICD-10:F00-F99] except I10, I50 and F42. But [ICD-10:K00-K95, n=1014 (15.6\%) with K27, K50 and K58] was statistically insignificant $(\mathrm{p}>.05)$ (Figure 2).

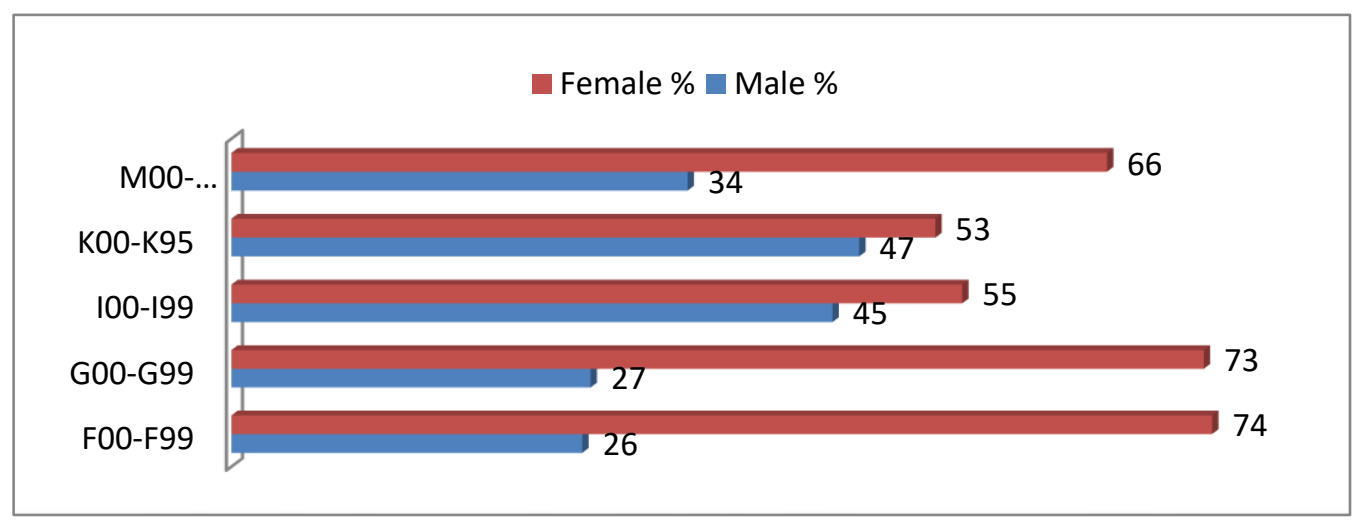

Figure 2. The pattern of distribution of non communicable diseases morbidity based on gender

\section{DISCUSSION}

The present study reflected the burden of disease morbidity at the level of urban training centre. The comprehensive analysis of the morbidity pattern reflected the burden of different diseases in particular area and helped us in the betterment for the evolution of new health planning strategies. As per the finding of our study majority of patients were females $(59.2 \%$ versus $40.2 \%)$. This could be explained partly from the socalled "male-female health survival paradox" (i.e., males report better health than females, but encounter higher mortality at all ages) [7]. The diseases in which we found extreme over presentation $(p<0.0001)$ of female patients were nervous system disorders, depression, ischemic heart disease and the diseases of musculoskeletal among non-infectious diseases, typhoid and gastroenteritis among the infectious diseases. It was found that the prevalence of depression is higher among this study group when compared to national prevalence [8]-[9]. We also found that there is an increased burden of depression among women which has been already emphasized among Indian women in earlier studies [10]. This may be explained by the fact a recent meta-analysis has found that being female was significantly associated with depression after natural disasters adjust five months before the start of study there was massive flooding in Uttarakhand to which as of 16 July 2013 [11]. According to data statistics provided by National Disaster management authority government of India more than 4,094people were "presumed dead." Our study had more females with diagnosis of ischemic heart disease which is in contrary to earlier findings [12]. Disorders of respiratory system were more frequently diagnosed in males (Table 2 and 3). These findings are in accordance with the earlier done studies [12]-[13].

Majority of patients who had visited us belonged to the age group (while reviewing age distribution in various diseases we found similar trends with diseases like osteoarthritis ,hypertension, COPD occurring in geriatric age group and infectious diseases mostly occurring in younger age group (Figure 4). Earlier works have emphasized huge burden of chronic non communicable diseases among geriatric age group in India [14]. 


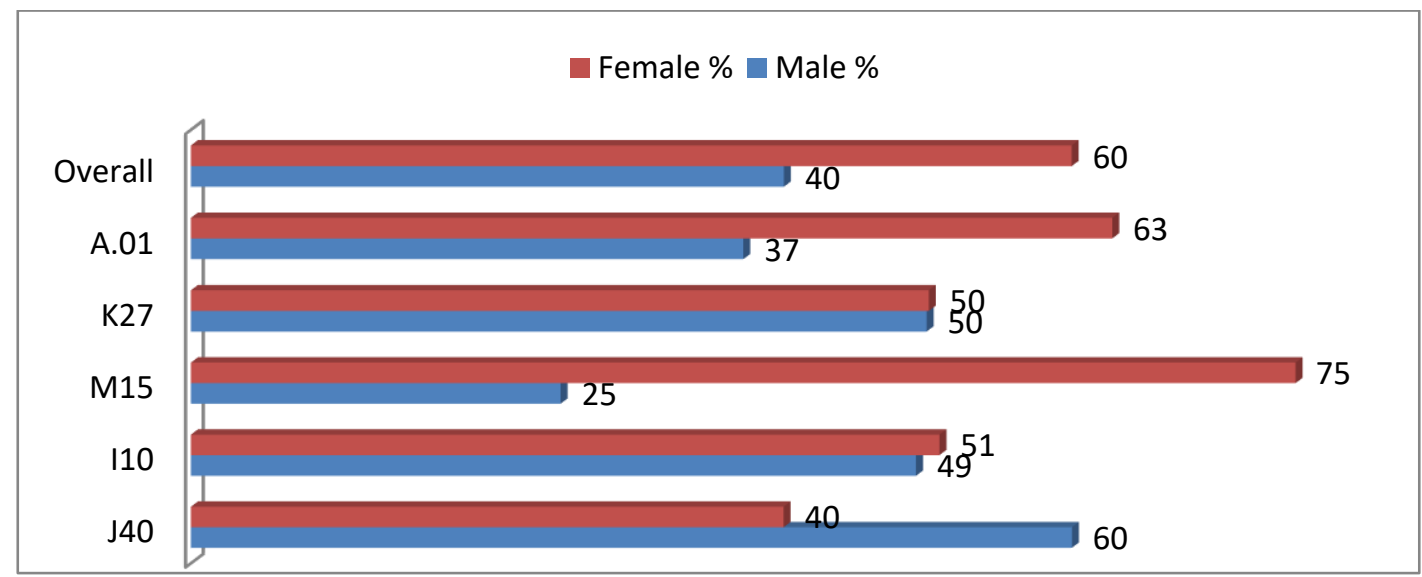

Figure 3. Distribution of overall top five morbidities in Srinagar city based on gender

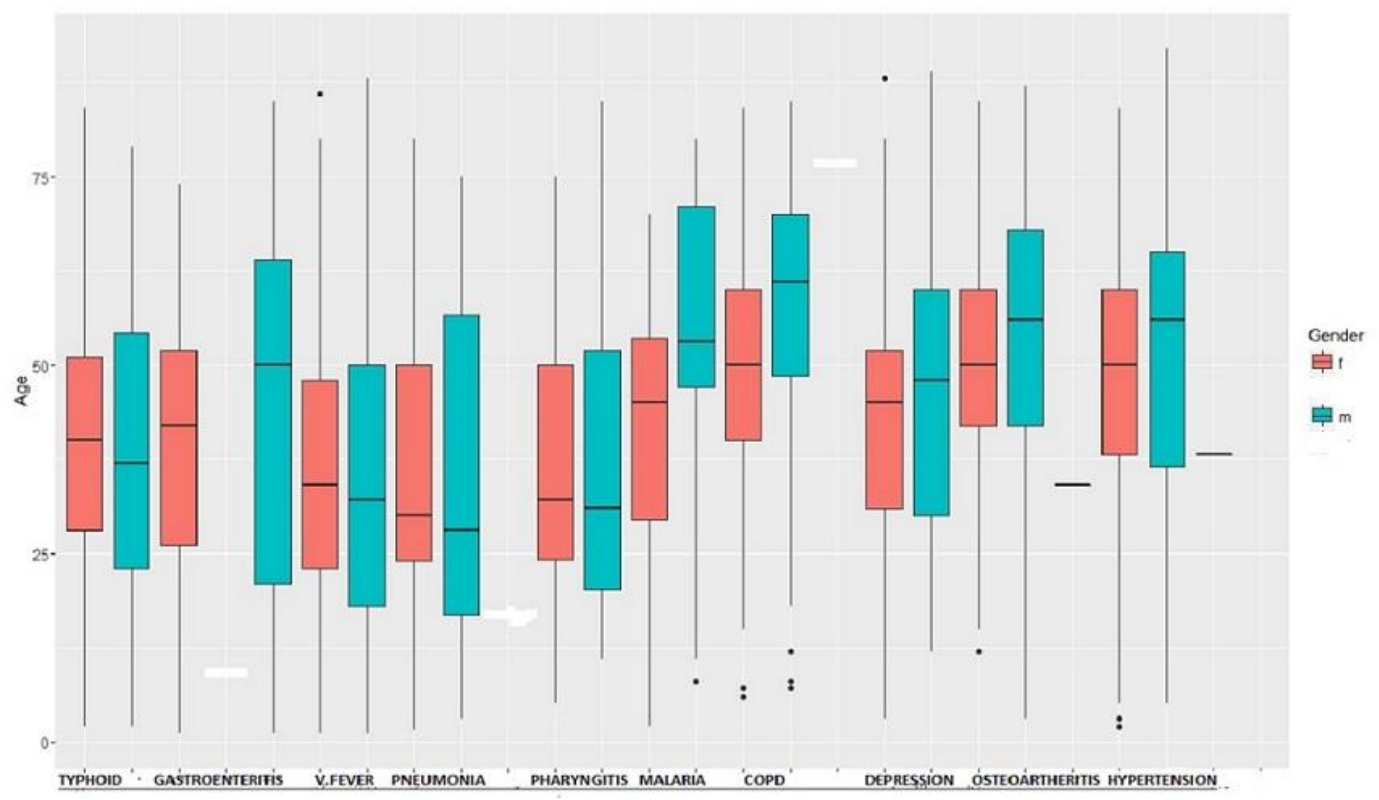

Figure 4. Graphical distribution of morbidities based on the age

Our study also confirms that out country still face challenges of both communicable and NCDs, although majority $(70 \%)$ of the patients who presented to our OPD were suffering from NCDs. Among communicable diseases there was a higher proportion of typhoid and gastroenteritis cases (24\% and $7 \%$ ) in OPD which contradicts observation in an earlier study [15]-[16]. Most of them report upper respiratory infections as most common infectious disease [13]-[17]. This difference may be explained by the fact that this study started after six months in Uttarakhand, having witnessed a devastating flood which crippled sanitation and waste disposal mechanism leading to increased incidence of gastroenteritis [18]. Also flooding has been identified as a significant risk factor for diarrheal illnesses caused by Salmonella enterica serotype Paratyphi A (paratyphoid fever)( comparison with community controls: OR, 4.52; 95\% CI, 1.90-10.73) [19]. Among non communicable disease, diseases of the musculoskeletal system and connective tissue are most common $(23 \%)$. Second in proportion comes the acid peptic disease (10\%), followed by hypertension $(8.7 \%)$

There are various limitation in our study most importantly, as our study was based at a single health centre, its generalisation is of due concern. There always remains a chance of misdiagnosis of cases as our study was OPD based. Despite its various limitations, this study aptly reflects the role of flood as a risk factor in diseases such as depression in women [8] and proportional increase in water-borne diseases like typhoid and gastroenteritis when compared with an earlier study conducted at geographical proximity [17]. This 
study suggests the need for more indepth analysis of after affects of a natural disaster like flood in a regional perspective.

\section{REFERENCES}

[1] Tyagi B. B., et al., "Morbidity Patterns Amongst Hospitalized Patients in a Secondary Care Hospital of Dehradun, Uttarakhand State India," Journal of General Practice and Medical Diagnosis, vol. 1, pp. 003, 2015.

[2] Deshpande R. V., "Morbidity Differentials in Rural Karnataka," The Journal of Family Welfare, vol. 4, pp. 9-14, 1998.

[3] Ghosh S. and Arokiasamy P., "Morbidity in India; Trends, Patterns and Differentials," Journal of Health Studies, vol. II, pp. 136-48, 2009.

[4] Report of the Working Group on Disease Burden for the 12th Five Year Plan WG3 ( 1 ): Communicable Diseases. Report Government of India Planning Commission. [cited 2014 May 10]. Available from: http://planningcommission.nic.in/aboutus/committee/wrkgrp12/health/WG_3_1communicable.pdf. 2011.

[5] Kumar R. and Sharma S. K., "Trend of communicable and non communicable morbidities in Uttartakhand State: A Systemic Review," Indian Journal of Community Health, vol/issue: 25(2), pp. 176-185, 2013.

[6] Kandpal S., et al., "Pattern of prevalence of risk factors for non-communicable diseases in the geriatric population of district Dehradun," Journal, Indian Academy of Clinical Medicine, vol/issue: 14(1), pp. 214-217, 2013.

[7] Ross P. L., et al., "Sex differences in health behavior and self assessed health in 11-15 years old children. A comparison between life conditions and health," UgeskrLaeger, vol/issue: 157(17), pp. 2447-51, 1995.

[8] Bohra N., et al., "Depression in women in Indian context," Indian J Psychiatry, vol/issue: 57(2), pp. S239-45, 2015.

[9] Kapoor R. and Singh G., "An epidemiological study of prevalence of depressive illness in rural Punjab," Indian J Psychiatry, vol/issue: 25(2), pp. 110-4, 1983.

[10] Singh I. J., "A study of morbidity pattern in a rural community," Heal PopulPerspect Issues, vol/issue: 2(3), pp. 193-206, 1979.

[11] Tang B., et al., "A meta-analysis of risk factors for depression in adults and children after natural disasters," $B M C$ Public Health, vol. 14, pp. 623, 2014.

[12] Gupta R. and Mohan I., "Trends in Coronary Heart Disease Epidemiology in India," Ann Glob Heal, vol/issue: 82(2), pp. 307-15, 2016.

[13] Article O., "Morbidity Profile of OPD Patients of an Urban Health and Training Center?" A Tool For The, vol/issue: 6(2), pp. 179-83, 2015.

[14] Joshi K., et al., "Morbidity profile and its relationship with disability and pyschological distress among elderly people in Northern India," Int J Epidemiol., vol/issue: 32(6), pp. 978-87, 2003.

[15] Kumari R., et al., "Morbidity profile and seasonal variation of diseases in a primary health center in kanpur district: a tool for the health planners," J Fam Med Prim care, vol/issue: 1(2), pp. 86-91, 2012.

[16] Pratap B., et al., "Morbidity profile of outdoor patients attending an urban health training center of South Andaman district, India," vol/issue: 3(11), pp. 3184-7, 2016.

[17] Diagnosis M., "General Practice and Medical Diagnosis Morbidity Patterns Amongst Hospitalized Patients in a Secondary Care Hospital of Dehradun, Uttarakhand State," pp. 1-10, 2015.

[18] Schwartz B. S., et al., "Diarrheal epidemics in Dhaka, Bangladesh, during three consecutive floods: 1988, 1998, and 2004," Am J Trop Med Hyg., vol/issue: 74(6), pp. 1067-73, 2006.

[19] Vollaard A. M., et al., "Risk factors for typhoid and paratyphoid fever in Jakarta, Indonesia," JAMA, vol/issue: 291(21), pp. 2607-15, 2004. 